\title{
Gastroduodenal Adenocarcinomas and Rectal Adenoma in a Cougar (Felis concolor) Infected with Helicobacter-like Organisms and Spirochetes
}

\author{
Yoshikazu YAMAZAKI ${ }^{1)}$, Itsushi AONO ${ }^{1)}$, Tatsuo OHYA ${ }^{2)}$, Tomoyuki SHIBAHARA ${ }^{3)}$ and Koichi KADOTA ${ }^{3) *}$ \\ ${ }^{1)}$ Ehime Chuo Livestock Hygiene Service Center, 641 Shonouchi, Masaki, Iyo, Ehime 791-3133, 2) Kyushu Research Station, National \\ Institute of Animal Health, 2702 Chuzan, Kagoshima 891-0105 and ${ }^{3)}$ Hokkaido Research Station, National Institute of Animal Health, \\ 4 Hitsujigaoka, Toyohira, Sapporo 062-0045, Japan
}

(Received 6 July 2001/Accepted 2 October 2001)

ABSTRACT. A 14-year-old female cougar died from gastroduodenal adenocarcinomas and rectal adenoma. At necropsy, polypoid tumor masses of various sizes were scattered on the mucosal surfaces of the stomach, duodenum, and rectum. Histologically, the gastric tumor was diagnosed as an intestinal type adenocarcinoma and the tumor cells metastasized to the mesenteric lymph nodes, spleen, and lung. Helicobacter-like organisms were detected in the lumina lined by foveolar epithelium. In the duodenum, the carcinoma cells were localized in the lamina propria and many of them were intensely positive for proliferating cell nuclear antigen (PCNA). In contrast, the rectal adenoma had a lower number of PCNA-positive cells. In the rectum, chronic inflammation with numerous spirochetes was also noted. These results indicated that the occurrence of the gastrointestinal tumors might be associated with the bacterial infection described above. KEY WORDS: cougar, gastroduodenal adenocarcinoma, Helicobacter.

J. Vet. Med. Sci. 64(2): 149-153, 2002

Helicobacter pylori infection is considered to be closely linked with active gastritis, peptic ulceration, gastric adenocarcinoma, and B-cell gastric lymphoma in humans [14, 18]. Helicobacter-like organisms are detected in various animal species including carnivores [10] and there have been reports on Helicobacter mustelae-associated gastritis, gastric adenocarcinoma [3] and lymphoma [2] in ferrets, and Helicobacter-associated gastric ulcer in a cougar [7]. In addition, intestinal spirochetosis has been reported to be pathogenic in pigs [17], dogs [1] and a cow [15], although the majority of intestinal spirochetes are commensals [4]. We have encountered gastroduodenal adenocarcinomas and reactal adenoma in an aged cougar infected with Helicobacter-like organisms and spirochetes. This report describes histological and immunohistochemical findings of the tumors, and the relationship with the bacterial infection is discussed.

A 14-year-old female cougar showed lusterless hair, loss of appetite, and severe emaciation, and died one month after the onset of clinical signs. At necropsy, pleural and pericar-

\footnotetext{
* Correspondence to: Kadota, K., Hokkaido Research Station, National Institute of Animal Health, 4 Hitsujigaoka, Toyohira, Sapporo 062-0045, Japan.
}

dial effusions had accumulated in large amounts. Polypoid tumor masses of various sizes were sparsely disseminated on the mucosal surfaces of the stomach, duodenum and rectum, and the mesenteric lymph nodes were enlarged. Tumor masses of 2 to $3 \mathrm{~cm}$ in diameter were scattered in the spleen, and nodules up to $3 \mathrm{~mm}$ in diameter were dispersed throughout the lungs.

Tissue specimens were fixed in $10 \%$ neutral buffered formalin and routinely processed, embedded in paraffin, sectioned at $4 \mu \mathrm{m}$, and stained with hematoxylin and eosin (HE). For special stainings, selected paraffin sections were subjected to periodic acid-Schiff (PAS) reaction, high iron diamine-alcian blue stain, $\mathrm{pH} 2.5$ (HID-AB), dual staining with galactose oxidase-cold thionin Schiff reaction (GOTS) and paradoxical concanavalin A stain (PCS) [13], and Warthin-Starry stain. Furthermore, additional sections were subjected to immunohistochemistry with the following primary antibodies: mouse monoclonal antibodies to proliferating cell nuclear antigen (PCNA) (BioGenex Laboratories, San Ramon, U.S.A.), CD79a (HM57) and myeloid/histiocyte antigen (MAC387) (Dako, Glostrup, Denmark), and rabbit polyclonal antibodies to chromogranin A (Nichirei Corporation, Tokyo, Japan), gastrin, glucagon, somatostatin

Table 1. Prevalence of mucin-producing cells in normal and neoplastic tissues

\begin{tabular}{|c|c|c|c|c|c|c|c|c|}
\hline & \multicolumn{3}{|c|}{ Stomach } & \multicolumn{3}{|c|}{ Duodenum } & \multicolumn{2}{|c|}{ Rectum } \\
\hline & $\begin{array}{l}\text { Foveolar } \\
\text { epithelium }\end{array}$ & $\begin{array}{l}\text { Pyloric } \\
\text { gland }\end{array}$ & Carcinoma & Crypt & $\begin{array}{l}\text { Gland of } \\
\text { Brunner }\end{array}$ & Carcinoma & Crypt & Adenoma \\
\hline GOTS & ++ & - & + & ++ & ++ & - & - & - \\
\hline PCS & - & ++ & + & - & ++ & - & - & - \\
\hline HID & - & - & ++ & ++ & - & $+\sim++$ & ++ & $+\sim++$ \\
\hline $\mathrm{AB}$ & ++ & - & ++ & ++ & - & + & ++ & $+\sim++$ \\
\hline
\end{tabular}

$-=$ absent; $+=$ rare or partial; $++=$ frequent or many. 

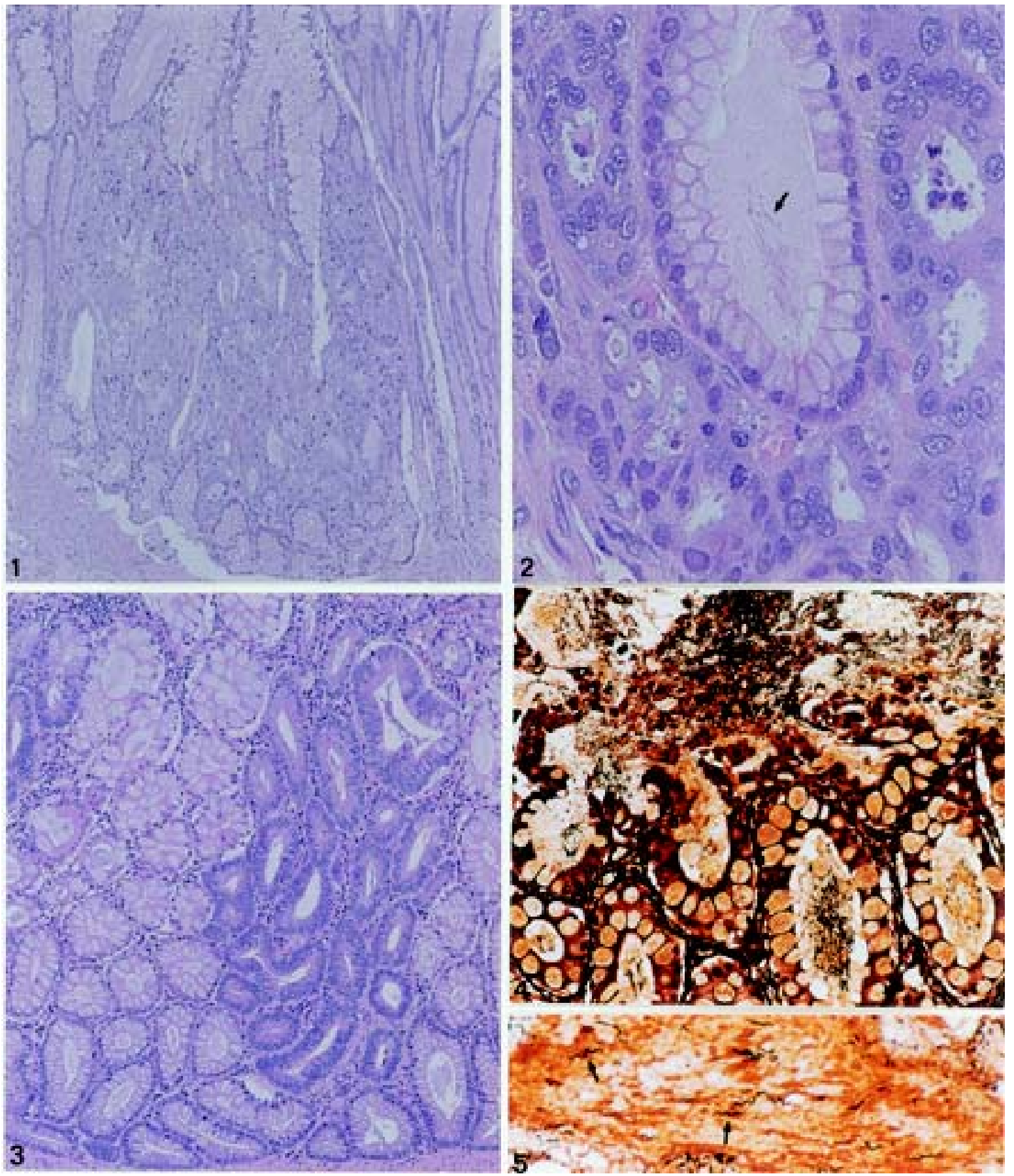

Fig. 1. Stomach. The neck zone of the pyloric region is replaced by tumor tissue, but remaining foveolar (top) and pyloric gland (bottom) cells are visible. HE. $\times 100$.

Fig. 2. Stomach. There are Helicobacter-like organisms (arrow) within a foveolar lumen, but not in the lumina of surrounding neoplastic glands. HE. $\times 600$.

Fig. 3. Rectum. A small adenomatous lesion is present in the lamina propria. A part of another lesion is also seen on the upper lefthand corner. HE. $\times 100$.

Fig. 4. Rectum. Numerous silver-positive spiral organisms are present within the lumina of intestinal glands and on the mucosal surface. Warthin-Starry stain. $\times 100$.

Fig. 5. Rectum. Arrows indicate argyrophilic spirochetes with long spiral shapes. Warthin-Starry stain. $\times 600$. 


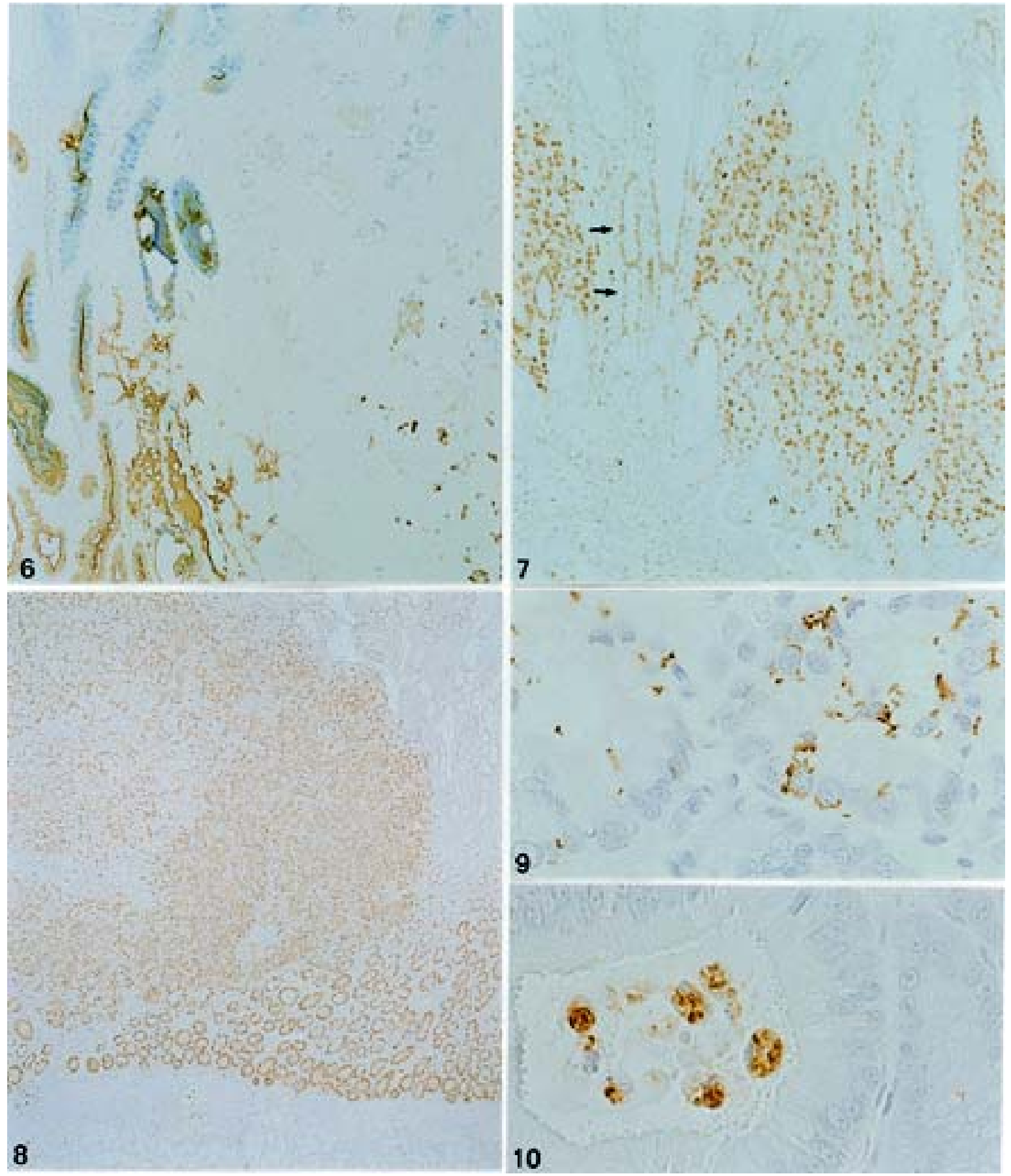

Fig. 6. Stomach. In the non-neoplastic mucosa (left), surface mucous cells are stained blue with GOTS, and pyloric gland cells are stained brown with PCS. Positive cells are few in the neoplastic tissue (right). GOTS-PCS. $\times 100$.

Fig. 7. Stomach. PCNA-positive carcinoma cells displace the gastric generating zone, but its residue is discernible (arrows). Immunostaining. $\times 100$.

Fig. 8. Duodenum. Many PCNA-positive cells are observed in this neoplastic lesion (top and left) and in the basal parts of the normal mucosa. Brunner's glands (bottom) are unreactive. Immunostaining. $\times 40$.

Fig. 9. Rectal epithelial cells are invaded by spirochetes, which exhibit immunoreactivity with the antibody to Brachispira pilosicoli. Immunostaining. $\times 600$.

Fig. 10. Helicobacter antigen is seen within intraluminal macrophages. Immunostaining. $\times 600$. 
(Biomeda Corporation, Foster City, U.S.A.), serotonin, secretin, neurotensin (BioGenex Laboratories, San Ramon, U.S.A.), CD3, H. pylori (Dako) and Brachispira pilosicoli. An avidin-biotin-peroxidase complex (ABC) kit (BioGenex) was used in the subsequent processes.

Histologically, the stomach had multiple neoplastic lesions consisting of densely packed tubular structures that varied in size and were located in the lamina propria of the pylorus (Fig. 1). There were large groups of malignant cells within some dilated lymphatic channels of the submucosa and serosa. In the surrounding mucosa, the epithelium was normal or hyperplastic but not metaplastic, and there were considerable numbers of lymphocytes and plasma cells and a few lymphoid follicles in the lamina propria. Globule leukocytes were marked in areas of foveolar cell hyperplasia. Occasionally, Helicobacter-like organisms were present within the foveolar lumina (Fig. 2), where neutrophil or macrophage infiltration was common. In the duodenum, neoplastic lesions were localized in the lamina propria, neoplastic tubules were smaller than in the pylorus, and a few clusters of Helicobacter-like organisms were found on the surfaces of intestinal villi. In the rectum, there were a large number of various-sized neoplastic lesions confined to the mucosa (Fig. 3), in which some neoplastic tubules contained many globule leukocytes. In addition, chronic proctitis characterized by epithelial cell desquamation and copious mucus production by hyperplastic goblet cells was observed in the non-neoplastic mucosa and was accompanied by numerous spirochetes (Figs. 4, 5).

In the pyloric carcinoma, the neoplastic cells were cuboidal or columnar and had large vesicular nuclei with prominent nucleoli. In metastatic lesions, neoplastic tubules were composed largely of columnar epithelial cells with stratification of the nuclei. In the duodenum carcinoma, the neoplastic cells resembled cells in the lower part of crypts but their nuclei were more pleomorphic and had larger nucleoli. In the rectal adenoma, the cells tended to have abundant cytoplasm, and showed nuclear pleomorphism, though nucleoli were inconspicuous.

Histochemical results for mucin are presented in Table 1. In the pyloric carcinoma and its metastatic lesions, HID- or AB-positive cells were much more prominent than GOTSor PCS-positive ones (Fig. 6). In the rectal adenoma, there was great variety in the proportion of mucin-containing cells from field to field.

Immunohistochemically, PCNA-positive neoplastic cells were very large in number in the stomach and duodenum (Figs. 7, 8), but less numerous and uneven in distribution in the rectum. In the normal and hyperplastic mucosae, generative cell zones could be confirmed (Fig. 7). In the gastric and duodenal carcinomas and metastatic lesions, chromogranin-positive cells were widely dispersed and the majority were also positive for serotonin, whereas adenoma cells showing endocrine cell differentiation were few.

Helicobacter-like organisms and spirochetes were stained positively with antisera against $H$. pylori and $B$. pilosicoli, respectively, and both bacteria showed epithelial and interstitial invasion (Fig. 9). Phagocytosis of Helicobacter-positive material by intraluminal, intraepithelial and stromal macrophages and by intraluminal neutrophils was observed (Fig. 10). Most of the infiltrating lymphocytes in the pylorus were positive for CD3, and in places MAC387positive macrophages predominated.

Like the human gastric mucosa [13], the pyloric mucosa in the present case was demonstrated to have two types of mucus-secreting cells. Albeit infrequently, GOTS- and PCS-positive cells were discerned in primary and metastatic lesions. The gastric carcinoma cells were therefore thought to have metastasized to other organs and tissues. The neoplastic cells in the pylorus and duodenum exhibited a similar pattern of PCNA staining. In contrast, PCNA-positive cells were less numerous and unevenly distributed in the rectal neoplasm, and hence a diagnosis of adenoma was made.

Although human gastric adenocarcinomas may be phenotypically divided into gastric and intestinal types, they are usually composed of mixed populations with a predominance of one cell type [9]. In the present case, the majority of neoplastic cells were considered to be intestinal in type, because many HID- or AB-positive cells were detected, but GOTS- or PCS-positive ones were much smaller in number [9]. In the apparently normal or hyperplastic epithelim, however, there were no cells showing intestinal metaplasia, as was demonstrable by the absence of HID-positive cells and the lack of PCNA-positive cells in the deeper parts of the mucosa [11]. The intestinal-type neoplastic cells may have arisen directly from gastric epithelium, but not from the metaplastic one [6].

Human and ferret adenocarcinomas of the stomach are associated with Helicobacter pylori [14] and Helicobacter mustelae [3] infection, respectively. The fact that many infiltrative cells were observed like human Helicobacterassociated gastritis [12] suggests a close relationship between the gastric carcinoma and Helicobacter-like organisms in the present case. H. pylori was localized mainly on the surface mucous gel layer, especially that composed of the surface mucous cell-type mucin [16]. In our case, Helicobacter-like bacteria were seen within gastric pits containing a GOTS-positive mucous substance, and their number might have been quite different from the real one, because of the loss of the surface mucous gel layer during the tissue preparation process [16].

In a study on human intestinal spirochetosis, half of the patients were affected with large bowel cancer [5]. In the present case, chronic proctitis with a large number of spirochetes was observed. This suggests an unhealthy intrarectal environment which may increase the risk of tumor development in the rectum [8]. Intestinal spirochetes may be related to some enteropathies but may be overlooked, because of the difficulty in detecting them in HE preparations.

ACKNOWLEDGMENT. The authors wish to thank Dr. Hiroyoshi Ota, Department of Laboratory Medicine, Shinshu University School of Medicine, for his advice on performing histochemical staining. 


\section{REFERENCES}

1. Duhamel., G. E., Trott, D. J., Mathiesen, M. R., Tarasiuk, K., Lee, J. I. and Hampson, D. J. 1998. J. Clin. Microbiol. 36: 2264-2270.

2. Erdman, S. E., Correa, P., Coleman, L. A., Schrenzel, M. D., Li, X. and Fox, J. G. 1997. Am. J. Pathol. 151: 273-280.

3. Fox, J. G., Dangler, C. A., Sager, W., Borkowski, R. and Gliatto, J. M. 1997. Vet. Pathol. 34: 225-229.

4. Hamir, A. N., Trott, D., Palmer, M. and Stasko, J. 2001. Vet. Pathol. 38: 233-236.

5. Harland, W. A. and Lee, F. D. 1967. Br. Med. J. 3: 718-719.

6. Hattori, T., Kushima, R., Naito, H. and Noda, M. 1995. Pathol. Clin. Med. 13: 45-51 (in Japanese).

7. Hill, J. E., Khanolkar, S. S. and Stadtlander, C. T. K.-H. 1997. Vet. Pathol. 34: 50-51.

8. Horie, H., Kanazawa, K., Okada, M., Narushima, S., Itoh, K. and Terada, A. 1999. Eur. J. Cancer Prev. 8: 237-245.

9. Ishiguro, S., Tsuji, N., Terao, T., Yoshizato, K. and Tateishi, R. 1995. Pathol. Clin. Med. 13: 10-17 (in Japanese).
10. Jakob, W., Stolte, M., Valentin, A. and Schröder, H.-D. 1997. J. Comp. Pathol. 116: 21-33.

11. Kushima, R. and Hattori, T. 1998. Pathol. Clin. Med. 16: 1723 (in Japanese).

12. Nagura, H., Yabuki, N., Imatani, A. and Sasano, H. 1995. Pathol. Clin. Med. 13: 1671-1677 (in Japanese).

13. Ota, H., Katsuyama, T., Ishii, K., Nakayama, J., Shiozawa, T. and Tsukahara, Y. 1991. Histochem. J. 23: 22-28.

14. Parsonnet, J., Friedman, G. D., Vandersteen, D. P., Chang, Y., Vogelman, J. H., Orentreich, N. and Sibley, R. K. 1991. New Engl. J. Med. 325: 1127-1131.

15. Shibahara, T., Wada, Y., Sueyoshi, T., Ohya, T., Ishikawa, Y. and Kadota, K. 2000. Vet. Rec. 146: 585-586.

16. Shimizu, T., Akamatsu, T., Sugiyama, A., Ota, H. and Katsuyama, T. 1996. Helicobacter 1: 207-218.

17. Trott, D. J., Stanton, T. B., Jensen, N. S., Duhamel, G. E., Johnson, J. L. and Hampson, D. J. 1996. Int. J. Syst. Bacteriol. 46: 206-215.

18. Wotherspoon, A. C., Ortiz-Hidalgo, C., Falzon, M. R. and Isaacson, P. G. 1991. Lancet 338: 1175-1176. 